\title{
Synthesis of cyclic $N^{1}$-pentylinosine phosphate, a new structurally reduced cADPR analogue with calcium-mobilizing activity on PC12 cells
}

\author{
Ahmed Mahal ${ }^{\ddagger 1}$, Stefano D’Errico ${ }^{\ddagger 1}$, Nicola Borbone ${ }^{1}$, Brunella Pinto ${ }^{1}$, \\ Agnese Secondo ${ }^{2}$, Valeria Costantino ${ }^{1}$, Valentina Tedeschi ${ }^{2}$, Giorgia Oliviero ${ }^{* 1}$, \\ Vincenzo Piccialli ${ }^{3}$ and Gennaro Piccialli ${ }^{1,4}$
}

\section{Full Research Paper}

\section{Address:}

${ }^{1}$ Dipartimento di Farmacia, Università degli Studi di Napoli Federico II, Via D. Montesano 49, 80131, Napoli, Italy, ${ }^{2}$ Dipartimento di Neuroscienze e Scienze Riproduttive ed Odontostomatologiche, Università degli Studi di Napoli Federico II, Via Pansini 5, 80131 Napoli, Italy, ${ }^{3}$ Dipartimento di Scienze Chimiche, Università degli Studi di Napoli Federico II, Napoli, Italy and ${ }^{4}$ Institute of Protein Biochemistry, National Council Research of Italy, Via Pietro Castellino 111, 80131 Napoli, Italy

\section{Email:}

Giorgia Oliviero* - golivier@unina.it

* Corresponding author $\ddagger$ Equal contributors

Keywords:

calcium mobilization; cIDPR analogues; cyclic ADP-ribose (cADPR); cyclization
Beilstein J. Org. Chem. 2015, 11, 2689-2695.

doi:10.3762/bjoc. 11.289

Received: 31 July 2015

Accepted: 04 December 2015

Published: 22 December 2015

Associate Editor: K. N. Ganesh

(c) 2015 Mahal et al; licensee Beilstein-Institut.

License and terms: see end of document.

\begin{abstract}
Cyclic $N^{1}$-pentylinosine monophosphate (cpIMP), a novel simplified inosine derivative of cyclic ADP-ribose (cADPR) in which the $N^{1}$-pentyl chain and the monophosphate group replace the northern ribose and the pyrophosphate moieties, respectively, was synthesized. The role played by the position of the phosphate group in the key cyclization step, which consists in the formation of a phosphodiester bond, was thoroughly investigated. We have also examined the influence of the phosphate bridge on the ability of cpIMP to mobilize $\mathrm{Ca}^{2+}$ in PC12 neuronal cells in comparison with the pyrophosphate bridge present in the cyclic $N^{1}$-pentylinosine diphosphate analogue (cpIDP) previously synthesized in our laboratories. The preliminary biological tests indicated that cpIMP and cpIDP induce a rapid increase of intracellular $\mathrm{Ca}^{2+}$ concentration in PC12 neuronal cells.
\end{abstract}

\section{Introduction}

Nucleosides and nucleotides (NNs) are widely used as key intermediates and important core structures in the field of synthetic medicinal chemistry $[1,2]$. They represent versatile syn- thetic building blocks towards the synthesis of biologically relevant compounds such as antiviral and antineoplastic drugs [3-8], antibiotics and antifungal agents [9-11]. Furthermore, 
several NNs act as potent second messengers involved in the regulation of key metabolic pathways [12]. Among these NNs there is the cyclic ADP-ribose (cADPR 1, Figure 1), a metabolite strictly involved in the homeostasis of cellular calcium ions. CADPR is a second messenger that activates the ryanodine receptors of the sarcoplasmic reticulum and mobilizes $\mathrm{Ca}^{2+}$ ions in many cell types of protozoa, plants, animals and humans [13].
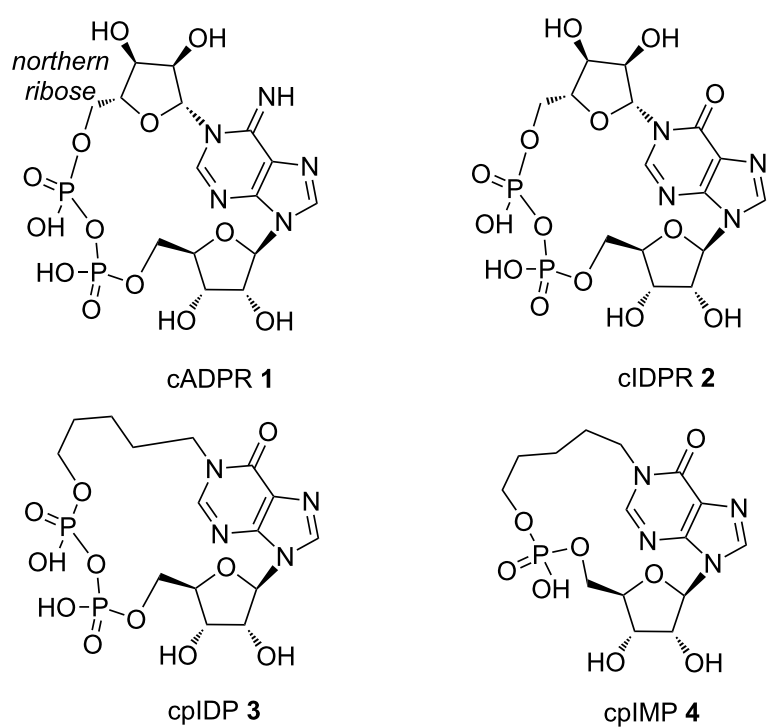

Figure 1: Structures of cADPR (1), cIDPR (2), cpIDP (3) and cpIMP (4).

Furthermore, there is a strong evidence that cADPR is an important second messenger in the nervous system where it is involved in the handling of $\mathrm{Ca}^{2+}$ ions that control several functions. Indeed, the administration of cADPR to cell cultures produces three patterns of response in terms of variation of intracellular concentration of calcium ions $\left(\left[\mathrm{Ca}^{2+}\right]_{\mathrm{i}}\right)$ : (a) a rapid response after direct microinjection of the messenger into the cells; (b) a slow variation of $\left[\mathrm{Ca}^{2+}\right]_{i}$ when cADPR is added to the cell culture medium; c) a progressive potentiation of $\left[\mathrm{Ca}^{2+}\right]_{\mathrm{i}}$ increasing due to a depolarization. In fact, cADPR induces $\mathrm{Ca}^{2+}$ release from presynaptic and postsynaptic intracellular stores and plays an important role in the activity-dependent synaptic plasticity, including long-term depression [14]. In addition, enzymes able to catalyze the hydrolysis of cyclic ADP-ribose to ADP-ribose are expressed ubiquitously in the mouse brain. Specifically, wild-type mice show the highest cyclase activity in the hypothalamus, and then in the cerebellum, cerebrum and posterior pituitary [15].

Unfortunately, the lability of the N-1 glycosidic bond of cADPR towards enzymatic and/or non-enzymatic hydrolysis to
ADP-ribose, even in a neutral aqueous solution, greatly hinders the studies aimed at elucidating its physiological role [16]. Several enzymes involved in the metabolism of cADPR have been described. Among them is the ubiquitous ADP-ribosyl cyclase, an enzyme first isolated from Aplysia Californica [17]. Using the Aplysia ADP-ribosyl cyclase many metabolite analogues of cADPR have been produced starting from $\mathrm{NAD}^{+}$ and $\mathrm{NADP}^{+}[18-21]$. However, the specificity of the enzymatic cyclization mechanism drastically limits its applicability for enzymatic or chemo-enzymatic procedures. For this reason, to obtain new cADPR derivatives the exploitation of chemical synthetic strategies is still necessary. A lot of modifications regarding the northern and southern ribose as well as the purine base of cADPR have been proposed so far [22,23]. Matsuda and co-workers were the first who synthesized new analogues of the cADPR in which the adenine base was replaced by a hypoxanthine ring [24]. This kind of modification produced the cyclic inosine diphosphate ribose (cIDPR) 2 which proved to be stable in hydrolytic physiological conditions and showed significant $\mathrm{Ca}^{2+}$ mobilizing activity, thus fostering the synthesis of a variety of cIDPR analogues. In particular, the N1, N9 and C8-substituted cIDPR were the most interesting [24-33]. In the last few years several cIDPR analogues were also synthesized in our laboratory [34-37]. Among these, the $N^{1}$-pentyl analogue cpIDP (3, Figure 1) [34] showed interesting activity on the PC12 cell line previously differentiated with the Nerve Growth Factor (NGF) (data not previously published). Starting from these data, we here report the synthesis and the preliminary biological activity of the new cyclic $N^{1}$-pentylinosine monophosphate (cpIMP) (4, Figure 1), in which the pyrophosphate group of $\mathbf{3}$ was replaced by a monophosphate moiety connecting the southern ribose with the $N^{1}$-pentyl chain. The here reported results significantly contribute to the understanding of the role played by the pyrophosphate moiety of cADPR and cIDPR analogues on the mobilization of $\mathrm{Ca}^{2+}$ ions. To date, such structure-activity relationship has only been poorly investigated [3841]. We anticipate here that compounds 3 and 4 induce the same effect on $\mathrm{Ca}^{2+}$ mobilization in NGF-differentiated PC12 cells. In particular, both compounds produced a transient increase of intracellular concentration of $\mathrm{Ca}^{2+}$ when added to the cells, thus demonstrating their ability to cross the plasma membrane.

\section{Results and Discussion Chemistry}

The key step for the preparation of all cADPR/cIDPR analogues is the macrocyclization via pyrophosphate bond formation, which is usually performed by joining the two phosphate moieties at the end of the multistep synthesis [24-29]. Similarly, the preparation of the new cpIMP derivative 4 could be performed by the cyclization of a monophosphate precursor via 
phosphodiester bond formation. For this purpose we investigated both the possible synthetic strategies (pathways A and B, Figure 2) in which the phosphate group (or its synthon) has been attached either on the end of the $N^{1}$-pentyl chain (precursor A) or on the 5 '-ribose position (precursor B).

At first, to obtain the cpIMP (4) we followed the synthetic pathway A by using the strategy reported in Scheme 1 that employed the $N^{1}$ - $\omega$-hydroxypentylinosine derivative $\mathbf{5}$ as the starting material [34]. Compound 5 was phosphorylated on the $\omega$-hydroxyalkyl function by using the phosphitylating chloroamidite agent $\mathbf{6}$. The reaction of $\mathbf{5}$ with $\mathbf{6}$ furnished the sole regioisomer 7 equipped with the reactive phosphorous(III) group. Unfortunately, the activation of the phosphoramidite function with $1 H$-tetrazole aimed at inducing the cyclization on the 5'-OH ribose function produced only a complex mixture.<smiles>O=c1c2ncn([C@@H]3O[C@H](CO)[C@@H](O)[C@H]3O)c2ncn1CCCCCc1ccccc1</smiles>

A

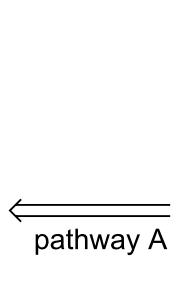

A

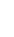

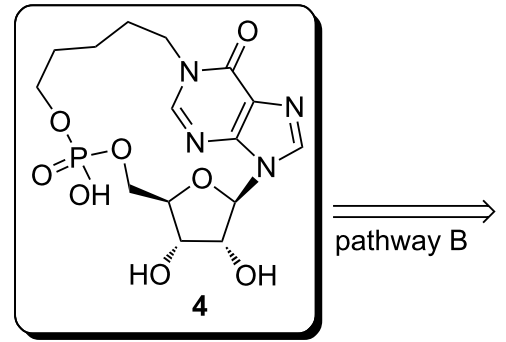

4

Figure 2: Synthetic strategies explored in the cyclization step via phosphodiester bond formation.<smiles>CC1(C)OC2[C@H](CO)OC(n3cnc4c(=O)n(CCCCCO)cnc43)[C@H]2O1</smiles>

5<smiles>CCOP(OC)N(C(C)C)C(C)C</smiles><smiles>CCOP(=O)(OCC)OCCCCCn1cnc2c(ncn2[C@@H]2O[C@H](CO)[C@@H]3OC(C)(C)O[C@H]32)c1=O</smiles>

9<smiles>COC(=O)OC(C)(C)N(C(C)C)C(C)C</smiles><smiles>COP(OCCCCCn1cnc2c(ncn2C2O[C@H](CO)C3OC(C)(C)OC32)c1=O)N(C(C)C)C(C)C</smiles>

7<smiles>COP(=O)(O)OCCCCCn1cnc2c(ncn2C2O[C@H](CO)[C@@H]3OC(C)(C)OC23)c1=O</smiles>

10<smiles>CC1(C)OC2C(CO)OC(n3cnc4c(=O)n(CCCCCOP(=O)(O)O)cnc43)C2O1</smiles>

11<smiles></smiles>

B<smiles>C1=CC=C1</smiles>

no cyclization

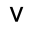

no cyclization

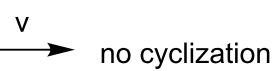

Scheme 1: i) (iPr) ${ }_{2} \mathrm{NP}(\mathrm{OCE}) \mathrm{Cl}$, DIPEA, THF, $1 \mathrm{~h}$, rt; ii) 1) $1 \mathrm{H}$-tetrazole, THF, 2) $t$-BuOOH, $2 \mathrm{~h}, \mathrm{rt}$; iii) 1 ) (iPr) ${ }_{2} \mathrm{NP}(\mathrm{OCE})_{2}, 1 \mathrm{H}$-tetrazole, THF, $2 \mathrm{~h}$, rt, 2) $t$-BuOOH, $2 \mathrm{~h}, \mathrm{rt}$; iv) TEA/pyridine, $1: 1 \mathrm{v} / \mathrm{v}, 16 \mathrm{~h}, \mathrm{rt}$; v) activating agent (EDC in DMF or DCC in DMF or MSNT in pyridine) $16 \mathrm{~h}, \mathrm{rt}$; vi) conc. aq $\mathrm{NH}_{4} \mathrm{OH}, \mathrm{MeOH}, 50^{\circ} \mathrm{C}, 16 \mathrm{~h}$. 
No traces of the target cyclic compound were detected after the usual phosphorous oxidation step.

This failure prompted us to use the alternative phosphitylating reagent bis(cyanoethyl)phosphoramidite $\mathbf{8}$, which, after the regioselective reaction with the 5'-hydroxyalkyl function of 5 led to the phosphotriester product 9 after the phosphorous oxidation with $t$-BuOOH. Starting from 9 we explored two synthetic routes, differing for the degree of esterification at the phosphate moiety, to achieve the cyclization of the 17-membered ring of 4 . The treatment of 9 with a mixture of triethylamine/pyridine furnished the phosphodiester product $\mathbf{1 0}$ in almost quantitative yield. Instead, the complete removal of both 2-cyanoethyl groups of 9 with concentrated aqueous ammonia gave the phosphomonoester 11. Unfortunately, neither linear precursors $\mathbf{1 0}$ nor $\mathbf{1 1}$ underwent the expected cyclization step, even when treated with the most common phosphate activating agents (EDC, DCC, MSNT) in very diluted conditions. In our opinion, the target intramolecular cyclizations failed because of the poor mobility of the 5'-OH ribose function, as well as because of the unfavourable anti conformation of the $\mathrm{N}$-glycosidic bond induced by the presence at the $\mathrm{N} 1$ position of the purine base of the bulky $\omega$-phosphate adduct formed with the activating agent.

For this reason, we decided to switch to the synthetic pathway B (Figure 2), in which the monophosphate group is installed at the 5 '-ribose position. This strategy, reported in Scheme 2, used as the starting material the 5'-TBDMS-2',3'-O-isopropylideneinosine (12). The protected inosine 12 was initially converted into the $N^{1}$-dinitrophenyl derivative $\mathbf{1 3}$, which, after reaction with the 5-aminopentan-1-ol, furnished the $N^{1}-\omega$-hydroxypentylinosine derivative 14 [35]. This compound was acetylated on the $\omega$-hydroxy function (compound 15) and then deprotected on the 5 '-hydroxy function thus obtaining 16. The phosphorylation of the 5 '-OH function of $\mathbf{1 6}$, by using the (iPr $)_{2} \mathrm{NP}(\mathrm{OCE})_{2} /$ $t$-BuOOH system, already used in the preparation of compound 9, furnished the 5'-O-phosphotriester inosine derivative 17. The treatment of $\mathbf{1 7}$ with concentrated aqueous ammonia allowed the removal of both the OCE phosphate protecting groups together with the acetate function, thus obtaining the key intermediate $\mathbf{1 8}$ as triethylammonium salt after HPLC purification. The derivate 18, dissolved in DMF at the final concentration of $2 \mathrm{mM}$ was treated with EDC (1.2 equiv) and the reaction allowed to stand at room temperature for $48 \mathrm{~h}$. From this mixture it was possible to isolate cyclic compound 19 (30\% cyclization yield) whose structure was confirmed by NMR and highresolution mass analyses. Eventually, the treatment of compound 19 with aqueous $20 \%$ TFA afforded the target compound 4 .

\section{$\mathrm{Ca}^{2+}$-mobilizing activity of $\mathbf{3}$ and $\mathbf{4}$ in PC12 cells}

To study the biological activity of compounds 3 and $\mathbf{4}$, we evaluated their effect on the mobilization of $\mathrm{Ca}^{2+}$ ions in $\mathrm{PC} 12$ cells differentiated with NGF. Interestingly, compounds $\mathbf{3}$ and $\mathbf{4}$<smiles>[R]n1cnc2c(ncn2[C@@H]2O[C@H](COCC(C)C)[C@H]3OC(C)(C)O[C@H]32)c1=O</smiles><smiles>[R]CCCCCn1cnc2c(ncn2[C@@H]2O[C@H](COC(C)C)[C@@H]3OC(C)(C)O[C@H]32)c1=O</smiles><smiles>CC(=O)OCCCCCn1cnc2c(ncn2C2O[C@H](CO)[C@@H]3OC(C)(C)OC23)c1=O</smiles>
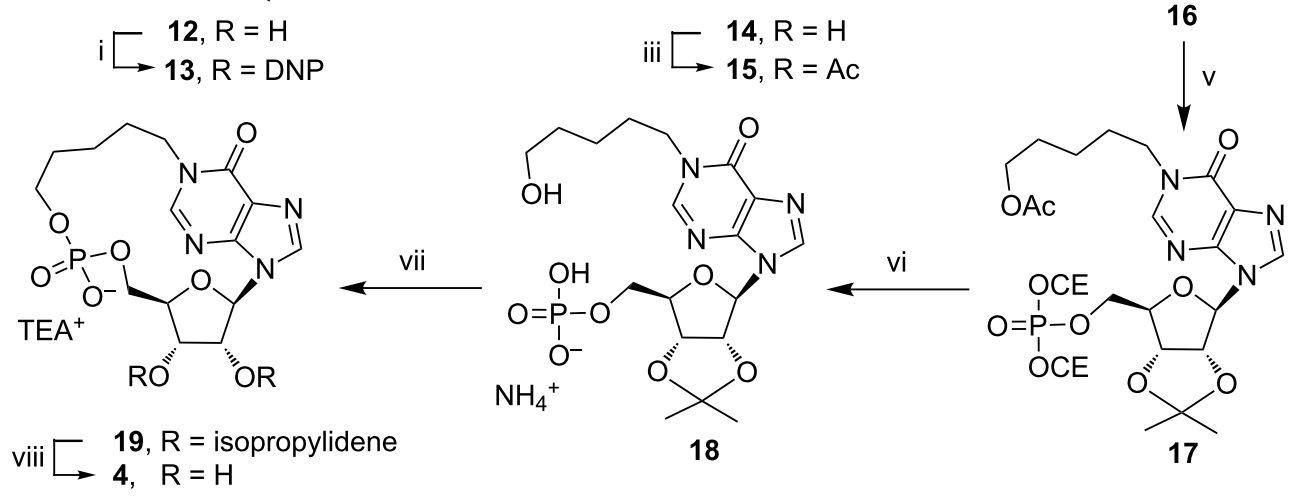

Scheme 2: i) DNCB, $\mathrm{K}_{2} \mathrm{CO}_{3}$, DMF, $4 \mathrm{~h}, 80^{\circ} \mathrm{C}$; ii) 5-aminopentan-1-ol, DMF, $16 \mathrm{~h}, 50^{\circ} \mathrm{C}$; iii) $\mathrm{Ac}_{2} \mathrm{O}$, pyridine, $2 \mathrm{~h}$, rt, iv) $\mathrm{NH}_{4} \mathrm{~F}, \mathrm{MeOH}, 16 \mathrm{~h}$, reflux; v) 1) (iPr) ${ }_{2} \mathrm{NP}(\mathrm{OCE})_{2}, 1 \mathrm{H}$-tetrazole, THF, $2 \mathrm{~h}$, rt, 2) $t$-BuOOH, $2 \mathrm{~h}$, rt; vi) conc. $\mathrm{NH}_{4} \mathrm{OH}_{(\mathrm{aq})}, \mathrm{MeOH}, 50{ }^{\circ} \mathrm{C}, 16 \mathrm{~h}$; vii) EDC, DMF; viii) TFA, $\mathrm{H}_{2} \mathrm{O}, 16 \mathrm{~h}, \mathrm{rt}$. 
caused a rapid and transient increase of the intracellular $\left[\mathrm{Ca}^{2+}\right]$ $\left(\left[\mathrm{Ca}^{2+}\right]_{\mathrm{i}}\right)$ when added to the medium at the concentration of $100 \mathrm{nM}$ (Figure 3). This pattern of response could be ascribed to the initial release of $\mathrm{Ca}^{2+}$ ions from the intracellular organelles followed by a depolarization-induced $\mathrm{Ca}^{2+}$ influx. The biological assays also confirmed that the cIDPR analogues 3 and $\mathbf{4}$ retained the ability to pass the plasma membrane of neuronal cells.

\section{Conclusion}

cADPR is a second messenger synthesized by neuronal cells that modulates the $\mathrm{Ca}^{2+}$ homeostasis in the nervous system [42]. Unfortunately, cADPR is characterized by a low ability to cross the plasma membranes. This behaviour hinders the studies on the effects of cADPR on cell functions. To overcome this limitation and to understand the role played by the pyrophosphate bridge on the biological activities of cADPR, we synthesized the lipophilic derivative cpIMP (4) in which the pyrophosphate group of $\mathbf{3}$ was replaced by a monophosphate moiety connecting the southern ribose with the $N^{1}$-pentyl chain. We compared the activity of $\mathbf{4}$ in modulating the concentration of $\left[\mathrm{Ca}^{2+}\right]_{\mathrm{i}}$ with that of the previously synthesized cpIDP (3). To study the effect of $\mathbf{3}$ and $\mathbf{4}$ on $\left[\mathrm{Ca}^{2+}\right]_{i}$, these compounds were added to PC12 cells previously differentiated with NGF at the concentration of $100 \mathrm{nM}$. Both compounds caused a fast and transient increase in $\left[\mathrm{Ca}^{2+}\right]_{\mathrm{i}}$. This pattern of response could be ascribed to the initial release of $\mathrm{Ca}^{2+}$ from intracellular organelles followed by a depolarization-induced $\mathrm{Ca}^{2+}$ influx. The reported preliminary results indicate that 3 and 4 possess almost the same activity, thus indicating that the role of the pyrophosphate bridge is not stringent and that the introduction of an alkyl chain in the $\mathrm{N} 1$ position of the purine base improves the permeation of the cell membrane by passive diffusion or through an active uptake system expressed on the membrane.

\section{Experimental \\ General}

All solvents were dried by standard methods and all reactions were carried out under inert atmosphere (argon or nitrogen). All reagents were obtained and used from commercial sources
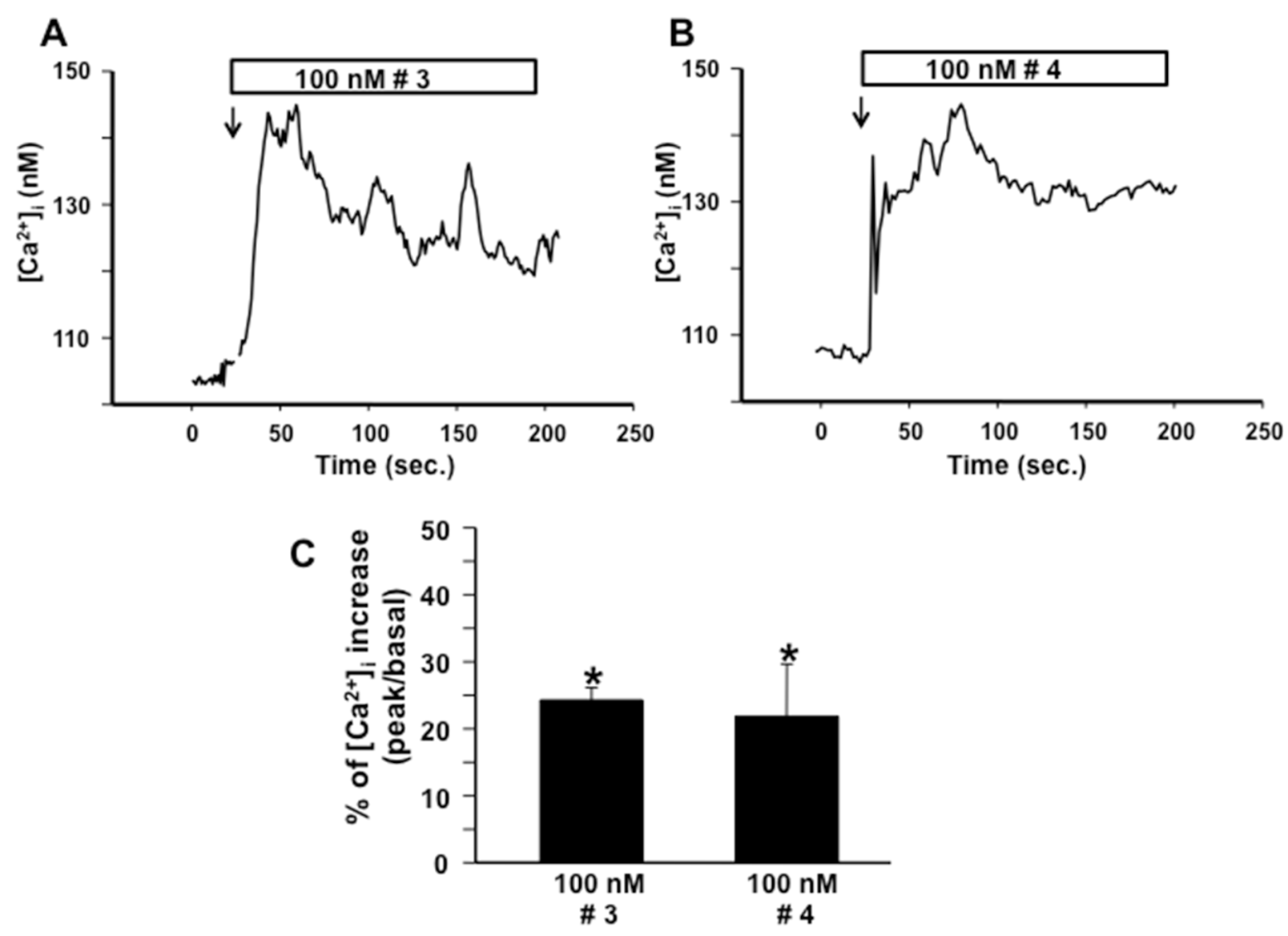

Figure 3: Effect of 3 and 4 on intracellular $\left[\mathrm{Ca}^{2+}\right]$ in NGF-differentiated PC12 cells. (A) and (B): representative single-cell traces of the effect of 3 and $4(100 \mathrm{nM})$ on $\left[\mathrm{Ca}^{2+}\right]_{i}, .(\mathrm{C})$ : quantification of $\left[\mathrm{Ca}^{2+}\right]_{\mathrm{i}}$ increase calculated, after the addition of each compound, as the percentage change of plateau/ basal value. Each bar represents the mean ( \pm S.E.M.) of the values obtained in three independent experimental sessions. For each experiment, 10 to 40 individual cells were monitored. ${ }^{*}, P<0.05$ versus basal level. 
(Sigma-Aldrich, Germany) without further purification. ${ }^{1} \mathrm{H}$ and ${ }^{13} \mathrm{C}$ NMR experiments were performed using a Varian Mercury Plus $400 \mathrm{MHz}$ spectrometer in $\mathrm{CD}_{3} \mathrm{OD}, \mathrm{D}_{2} \mathrm{O}, \mathrm{CDCl}_{3}$ and acetone- $d_{6}$ solvents. Chemical shifts are reported in parts per million ( $\delta$ ) relative to residual solvents signals: $\mathrm{CD}_{2} \mathrm{HOD} 3.31$, HOD 4.80, $\left(\mathrm{CD}_{3}\right)\left(\mathrm{CD}_{2} \mathrm{H}\right) \mathrm{CO} 2.09$ for ${ }^{1} \mathrm{H}$ NMR and $\mathrm{CD}_{3} \mathrm{OD}$ 49.0 for ${ }^{13} \mathrm{C} \mathrm{NMR} .{ }^{31} \mathrm{P}$ NMR experiments were carried out on a Varian Unity INOVA $500 \mathrm{MHz}$ instrument in $\mathrm{CD}_{3} \mathrm{OD}$ solvent using $85 \% \mathrm{H}_{3} \mathrm{PO}_{4}$ as an external standard ( $\left.0 \mathrm{ppm}\right)$. High performance liquid chromatography (HPLC) was performed using a Jasco UP-2075 Plus pump equipped with a Jasco UV-2075 Plus UV detector and a $4.8 \times 150 \mathrm{~mm} \mathrm{C}-18$ reversed-phase column (particle size $5 \mu \mathrm{m}$ ) eluted with a linear gradient of $\mathrm{CH}_{3} \mathrm{CN}$ in $0.1 \mathrm{M}$ triethylammonium bicarbonate (TEAB) buffer (from 0 to $50 \%$ in $45 \mathrm{~min}$, flow $1.3 \mathrm{~mL} / \mathrm{min}$ ). UV spectra were recorded on a Jasco V-530 UV spectrophotometer. High-resolution MS spectra were recorded on a Bruker APEX II FT-ICR mass spectrometer using the electrospray ionization (ESI) technique. Column chromatography was carried out on silica gel-60 (Merck, $0.063-0.200 \mathrm{~mm}$ ) or on C-18 reversed-phase silica gel60 (Merck, 0.040-0.063 mm). Analytical TLC analyses were performed using $\mathrm{F}_{254}$ silica gel plates $(0.2 \mathrm{~mm}$ thick, Merck). TLC spots were detected under UV light $(254 \mathrm{~nm})$.

\section{Cell cultures and $\left[\mathrm{Ca}^{2+}\right]_{i}$ measurements}

PC12 cells, grown on plastic dishes in RPMI medium composed of $10 \%$ horse serum, $5 \% \mathrm{FBS}, 100 \mathrm{UI} / \mathrm{mL}$ penicillin and $100 \mu \mathrm{g} / \mathrm{mL}$ streptomycin, were differentiated in neurons with NGF ( $50 \mathrm{ng} / \mathrm{mL} ; 7$ days). Cells were cultured in an atmosphere of $5 \% \mathrm{CO}_{2}$. The culture medium was changed every 2 days. For microfluorimetric studies with Fura 2-AM, cells were seeded on glass coverslips (Fisher, Springfield, NJ, USA) coated with poly-L-lysine $(5 \mu \mathrm{g} / \mathrm{mL})$ (Sigma, St. Louis, Missouri, USA) and used at least $12 \mathrm{~h}$ after seeding. Intracellular $\mathrm{Ca}^{2+}$ concentration $\left(\left[\mathrm{Ca}^{2+}\right]_{\mathrm{i}}\right)$ was measured by single cell computer-assisted video QImaging [43]. Briefly, differentiated PC12 cells cultured on poly-L-lysine-coated glass coverslips were loaded with $10 \mu \mathrm{M}$ Fura-2AM for $1 \mathrm{~h}$ at $22{ }^{\circ} \mathrm{C}$ in Krebs-Ringer saline solution containing the following: $5.5 \mathrm{mM} \mathrm{KCl}, 160 \mathrm{mM} \mathrm{NaCl}$, $1.2 \mathrm{mM} \mathrm{MgCl}_{2}, 1.5 \mathrm{mM} \mathrm{CaCl}_{2}, 10 \mathrm{mM}$ glucose, and $10 \mathrm{mM}$ HEPES-NaOH, pH 7.4. At the end of the loading period, the coverslips were placed in a perfusion chamber (Medical System, Greenvale, NY, USA), mounted on a Zeiss Axiovert 200 microscope (Carl Zeiss, Germany) equipped with a FLUAR 40X oil objective lens. The experiments employed a digital imaging system composed of a MicroMax 512BFT cooled CCD camera (Princeton Instruments, Trenton, NJ, USA), LAMBDA 10-2 filter wheeler (Sutter Instruments, Novato, CA, USA), and Meta-Morph/MetaFluor Imaging System software (Universal Imaging, West Chester, PA, USA). After loading, the cells were illuminated alternately at 340 and $380 \mathrm{~nm}$ by a Xenon lamp.
The emitted light was passed through a $512 \mathrm{~nm}$ barrier filter. Fura-2AM fluorescence intensity was measured every 3 s. Forty to sixty-five individual cells were selected and monitored simultaneously from each cover slip. Results are presented as the cytosolic $\mathrm{Ca}^{2+}$ concentration. Calibrations used the relation of Grynkiewicz et al. [44] assuming that the KD for Fura-2AM was $224 \mathrm{nM}$.

\section{Supporting Information}

\section{Supporting Information File 1}

Structural characterizations.

[http://www.beilstein-journals.org/bjoc/content/

supplementary/1860-5397-11-289-S1.pdf]

\section{Acknowledgments}

The research leading to these results was funded by the Seventh Framework Programme (FP7) of the European Union 2007-2013 under grant agreement No. 229893 (BlueGenics) and by Regione Campania under POR Campania FESR 2007-2013 - O.O. 2.1 (FarmaBioNet).

\section{References}

1. Chu, C. K. Antiviral Nucleosides: Chiral Synthesis and Chemotherapy; Elsevier: Amsterdam, The Netherlands, 2003.

2. Simons, C.; Wu, Q.; Htar, T. T. Curr. Top. Med. Chem. 2005, 5, 1191-1203. doi:10.2174/156802605774463051

3. Lagoja, I. M. Chem. Biodiversity 2005, 2, 1-50. doi:10.1002/cbdv.200490173

4. Miura, S.; Izuta, S. Curr. Drug Targets 2004, 5, 191-195. doi:10.2174/1389450043490578

5. Parker, W. B.; Secrist, J. A.; Waud, W. R. Curr. Opin. Invest. Drugs 2004, 5, 592-596.

6. D’Errico, S.; Oliviero, G.; Amato, J.; Borbone, N.; Cerullo, V.; Hemminki, A.; Piccialli, V.; Zaccaria, S.; Mayol, L.; Piccialli, G. Chem. Commun. 2012, 48, 9310-9312. doi:10.1039/c2cc33511e

7. D’Errico, S.; Oliviero, G.; Borbone, N.; Amato, J.; D’Alonzo, D.; Piccialli, V.; Mayol, L.; Piccialli, G. Molecules 2012, 17, 13036-13044. doi:10.3390/molecules171113036

8. Caso, M. F.; D’Alonzo, D.; D’Errico, S.; Palumbo, G.; Guaragna, A Org. Lett. 2015, 17, 2626-2629. doi:10.1021/acs.orglett.5b00982

9. Kimura, K.-i.; Bugg, T. D. H. Nat. Prod. Rep. 2003, 20, 252-273. doi:10.1039/b202149h

10. Rachakonda, S.; Cartee, L. Curr. Med. Chem. 2004, 11, 775-793. doi:10.2174/0929867043455774

11. Knapp, S. Chem. Rev. 1995, 95, 1859-1876. doi:10.1021/cr00038a006

12. Clapper, D. L.; Walseth, T. F.; Dargie, P. J.; Lee, H. C. J. Biol. Chem. 1987, 262, 9561-9568.

13. Guse, A. H. Curr. Med. Chem. 2004, 11, 847-855. doi:10.2174/0929867043455602

14. Reyes-Harde, M.; Empson, R.; Potter, B. V. L.; Galione, A.; Stanton, P. K. Proc. Natl. Acad. Sci. U. S. A. 1999, 96, 4061-4066. doi:10.1073/pnas.96.7.4061 
15. Jin, D.; Liu, H.-X.; Hirai, H.; Torashima, T.; Nagai, T.; Lopatina, O.; Shnayder, N. A.; Yamada, K.; Noda, M.; Seike, T.; Fujita, K.; Takasawa, S.; Yokoyama, S.; Koizumi, K.; Shiraishi, S.; Tanaka, Y.; Hashii, M.; Yoshihara, T.; Higashida, K.; Islam, M. S.; Yamada, N.; Hayashi, K.; Noguchi, N.; Kato, I.; Okamoto, H.; Matsushima, A.; Salmina, A.; Munesue, T.; Shimizu, N.; Mochida, S.; Asano, M.; Higashida, H. Nature 2007, 446, 41-45. doi:10.1038/nature05526

16. Shuto, S.; Matsuda, A. Curr. Med. Chem. 2004, 11, 827-845. doi:10.2174/0929867043455639

17. Aarhus, R.; Graeff, R. M.; Dickey, D. M.; Walseth, T. F.; Lee, H. C. J. Biol. Chem. 1995, 270, 30327-30333. doi:10.1074/jbc.270.51.30327

18. Moreau, C.; Ashamu, G. A.; Bailey, V. C.; Galione, A.; Guse, A. H.; Potter, B. V. L. Org. Biomol. Chem. 2011, 9, 278-290. doi:10.1039/C0OB00396D

19. Inageda, K.; Takahashi, K.; Tokita, K.; Nishina, H.; Kanaho, Y.; Kukimoto, I.; Kontani, K.; Hoshino, S.; Katadat, T. J. Biochem. 1995, 117, 125-131.

20. De Flora, A.; Guida, L.; Franco, L.; Zocchi, E.; Buzzone, S.; Benatti, U.; Damonte, G.; Lee, H. C. J. Biol. Chem. 1997, 272, 12945-12951. doi:10.1074/jbc.272.20.12945

21. Fukushi, Y.; Kato, I.; Takasawa, S.; Sasaki, T.; Ong, B. H.; Sato, M.; Ohsaga, A.; Sato, K.; Shirato, K.; Okamoto, H.; Maruyama, Y. J. Biol. Chem. 2001, 276, 649-655. doi:10.1074/jbc.M004469200

22. Zhang, L.; Yue, J.; Zhang, L.-H. Chem. Rec. 2015, 15, 511-523. doi:10.1002/tcr.201402072

23. Guse, A. H. J. Chin. Pharm. Sci. 2013, 22, 127-136.

24. Fukuoka, M.; Shuto, S.; Minakawa, N.; Ueno, Y.; Matsuda, A. J. Org. Chem. 2000, 65, 5238-5248. doi:10.1021/jo0000877

25. Wagner, G. K.; Black, S.; Guse, A. H.; Potter, B. V. L. Chem. Commun. 2003, 1944-1945. doi:10.1039/b305660k

26. Gu, X.; Yang, Z.; Zhang, L.; Kunerth, S.; Fliegert, R.; Weber, K.; Guse, A. H.; Zhang, L. J. Med. Chem. 2004, 47, 5674-5682. doi:10.1021/jm040092t

27. Guse, A. H.; Gu, X.; Zhang, L.; Weber, K.; Krämer, E.; Yang, Z.; Jin, H.; Li, Q.; Carrier, L.; Zhang, L. J. Biol. Chem. 2005, 280, 15952-15959. doi:10.1074/jbc.M414032200

28. Swarbrick, J. M.; Potter, B. V. L. J. Org. Chem. 2012, 77, 4191-4197. doi:10.1021/jo202319f

29. Shuto, S.; Shirato, M.; Sumita, Y.; Ueno, Y.; Matsuda, A. J. Org. Chem. 1998, 63, 1986-1994. doi:10.1021/jo9717797

30. Huang, L.-J.; Zhao, Y.-Y.; Yuan, L.; Min, J.-M.; Zhang, L.-H. Bioorg. Med. Chem. Lett. 2002, 12, 887-889. doi:10.1016/S0960-894X(02)00033-1

31. Huang, L.-J.; Zhao, Y.-Y.; Yuan, L.; Min, J.-M.; Zhang, L.-H. J. Med. Chem. 2002, 45, 5340-5352. doi:10.1021/jm010530l

32. Takano, S.; Tsuzuki, T.; Murayama, T.; Sakurai, T.; Fukuda, H.; Arisawa, M.; Shuto, S. J. Org. Chem. 2015, 80, 6619-6627. doi:10.1021/acs.joc.5b00723

33. Tsuzuki, T.; Sakaguchi, N.; Kudoh, T.; Takano, S.; Uehara, M.; Murayama, T.; Sakurai, T.; Hashii, M.; Higashida, H.; Weber, K.; Guse, A. H.; Kameda, T.; Hirokawa, T.; Kumaki, Y.; Potter, B. V. L.; Fukuda, H.; Arisawa, M.; Shuto, S. Angew. Chem., Int. Ed. 2013, 52, 6633-6637. doi:10.1002/anie.201302098

34. Galeone, A.; Mayol, L.; Oliviero, G.; Piccialli, G.; Varra, M. Eur. J. Org. Chem. 2002, 4234-4238. doi:10.1002/1099-0690(200212)2002:24<4234::AID-EJOC4234>3.0.C $0 ; 2-8$

35. Oliviero, G.; D'Errico, S.; Borbone, N.; Amato, J.; Piccialli, V.; Varra, M.; Piccialli, G.; Mayol, L. Tetrahedron 2010, 66, 1931-1936. doi:10.1016/j.tet.2010.01.013
36. D’Errico, S.; Oliviero, G.; Borbone, N.; Amato, J.; Piccialli, V.; Varra, M.; Mayol, L.; Piccialli, G. Molecules 2011, 16, 8110-8118. doi:10.3390/molecules16098110

37. D’Errico, S.; Oliviero, G.; Borbone, N.; Amato, J.; Piccialli, V.; Varra, M.; Mayol, L.; Piccialli, G. Molecules 2013, 18, 9420-9431. doi:10.3390/molecules18089420

38. Qi, N.; Jung, K.; Wang, M.; Na, L. X.; Yang, Z. J.; Zhang, L. R.; Guse, A. H.; Zhang, L. H. Chem. Commun. 2011, 47, 9462-9464. doi:10.1039/c1cc13062e

39. Aarhus, R.; Gee, K.; Lee, H. C. J. Biol. Chem. 1995, 270, 7745-7749. doi:10.1074/jbc.270.13.7745

40. Zhang, F.-J.; Yamada, S.; Gu, Q.-M.; Sih, C. J. Bioorg. Med. Chem. Lett. 1996, 6, 1203-1208. doi:10.1016/0960-894X(96)00207-7

41. Xu, L.; Walseth, T. F.; Slama, J. T. J. Med. Chem. 2005, 48, 4177-4181. doi:10.1021/jm049469l

42. Higashida, H.; Hashii, M.; Yokoyama, S.; Hoshi, N.; Asai, K.; Kato, T. J. Neurochem. 2001, 76, 321-331. doi:10.1046/j.1471-4159.2001.00082.x

43. Secondo, A.; Staiano, R. I.; Scorziello, A.; Sirabella, R.; Boscia, F.; Adornetto, A.; Valsecchi, V.; Molinaro, P.; Canzoniero, L. M.; Di Renzo, G.; Annunziato, L. Cell Calcium 2007, 42, 521-535. doi:10.1016/j.ceca.2007.01.006

44. Grynkiewicz, G.; Poenie, M.; Tsien, R. Y. J. Biol. Chem. 1985, 260, 3440-3450.

\section{License and Terms}

This is an Open Access article under the terms of the Creative Commons Attribution License (http://creativecommons.org/licenses/by/2.0), which permits unrestricted use, distribution, and reproduction in any medium, provided the original work is properly cited.

The license is subject to the Beilstein Journal of Organic Chemistry terms and conditions:

(http://www.beilstein-journals.org/bjoc)

The definitive version of this article is the electronic one which can be found at: $\underline{\text { doi:10.3762/bjoc.11.289 }}$ 